\title{
Legal Origins and the Financial Conservatism of Private Firms
}

\author{
Hongzhong Fan ${ }^{1}$, Mirza Nouman Ali Talib ${ }^{1} \&$ Pan $_{\text {Chen }}{ }^{1}$ \\ ${ }^{1}$ School of Economics, Huazhong University of Science and Technology, Wuhan, P.R. China \\ Correspondence: Mirza Nouman Ali Talib, School of Economics, Huazhong University of Science and \\ Technology, Wuhan, P. R. China. E-mail: noumanmirza@ hust.edu.cn
}

Received: February 25, 2019

Accepted: March 15, 2019

Online Published: April 15, 2019

doi:10.5539/ijef.v11n5p103

URL: https://doi.org/10.5539/ijef.v11n5p103

\begin{abstract}
Following the literature of corporate law and finance, our study emphasizes on differences of legal origins and their laws influencing the capital structures of the private firms following suboptimal conservative policies. The countries considered in each legal origin represents common law countries (UK, Australia, India, Pakistan and Thailand) and Roman backed civil law countries (Japan, South Korea, Germany) respectively. The time series considered for the study is 2000-2017. The findings provide that the conservative private firms are smaller in size with less investments but are positively related with profitability in both legal origins. However, the dividend payouts and non-debt tax shields have significant positive relation with conservative policies in civil law countries. It shows that the presence of minority shareholders' protection law in civil law countries directs the firms to pay more dividends which may also help them in reducing agency costs. We further exhibit that, before financial crises of 2008, the conservative firms in both legal origins are less directed towards dividends, especially in common law countries. Nevertheless, private conservative firms of civil law countries are more inclined towards dividend payouts after financial crises. The study implicates that the difference of laws in legal origins affect the capital structures of the conservative private firms. It further provides that because of the less effective credit markets, private firms may also be forced to adopt conservative policies in civil law countries but may also have less agency problems due to high probability of having dividend payouts.
\end{abstract}

Keywords: legal origins, financial conservatism, financial crises, dividends, tax shields

\section{Introduction}

Legal environment of the country affects the financial decisions of the firms. With the difference in the laws, capital market structures, firms follow different strategic financial policies (Porta et al., 2000). Investor protection law in common law countries provides better atmosphere for future growth yet it may lead to agency problems if minority shareholders or debtors are ignored in taking financial decisions. Contrary to that, civil law countries protect the minority shareholders'(agents) rights which may reduce the agency problems but may hinder growth. Thus, difference in legal systems affects the financial decisions and structural policies of the firms.

Bigelli, Martín-Ugedo and Sánchez-Vidal (2014) provides that private firms are constrained than public firms. Public firms are found to be large in size and private firms have limited assets and investments. The policies adopted influence the firms' capital structures irrespective of their size. Progressive policies may highlight risk taking characteristics in contrast to the conservative policies leading to risk averse behaviors.

One of the most important risk averse policies being highlighted in recent decades are the financially conservative policies. A number of scholars (Graham, 2000; Lemmon, Roberts, \& Zender, 2008; Korteweg, 2010; Bigelli, Martín-Ugedo, \& Sánchez-Vidal, 2014) have established a fact that firms do adopt risk averse policies to either believe in future growth or because of their financial distress. Conservative financial behavior has also been investigated by Bessler et al. (2013); Strebulaev and Yang (2013) focusing on zero-leverage firms. Bigelli (2014) by calculating net financial position presents that conservative private firms in Italy are smaller in size and are financially constrained. It is noteworthy that Italy belongs to the pool of roman backed civil law countries with narrow capital markets, less property rights, lower creditor's protection characterizing the preferences of internal funds usage. On the other side, Bessler et al. (2013) also presents that despite of efficient capital markets and better bank credit access, firms exhibit the adoption of zero leverage policies.

The existing literature on financial conservative policies describes conservatism in literature to the financial 
conservative policies while dealing with both policies to create suboptimal or extremely conservative policies. Minton and Wruck (2001) has taken the lowest debt quintile for five consecutive years whereas the firms are considered "conservative" if the annual ratio of total debt to total assets belongs to the first $20 \%$ for five consecutive years. Mikkelson and Partch (2003) has considered the firms "conservative" if it holds more than 25\% of the cash and equivalents for five conservative years. Bigelli et al. (2014) has brought a new definition of conservatism by calculating the difference of High cash and low leverage. Iona and Leonida (2016) adopted a fixed threshold by adding both policies of high cash reserves and low leverage and observed its relationship with ownership structure in UK. By following Iona and Leonida (2016), we have also considered both policies of low leverage and high cash reserves of Minton and Wruck (2001) and Mikkleson and Partch (2003).

Notwithstanding the existing literature on conservatism, there is no study conducted on the differences of legal systems and the financial policies adopted by the conservative private firms. The importance of considering private firms is their growing number in different countries irrespective of their legal origins. UK, a common law country has 97.5 percent of the private firms hold two third of the total assets Brav (2009) whereas, firms in Italy, a civil law country 4 million private firms account for 97 percent of the workforce (Bigelli, 2014). Secondly, Public firms have numerous shareholders while private firms have limited ownership. To retain their ownership, private firms prefer to rely on internal funds and have reluctance to engage with capital markets. In addition, the private firms are likely to be financially constrained and smaller in size than public firms.

Our paper aims to observe the differences in the capital structures of conservative private firms according to their existence in different legal origins. Though our results are limited to the private firms, they could be extended to public firms and more importantly to conduct comparative analysis on growth strategies according to their legal systems. More importantly, though the pool of French civil law countries is much bigger than those of German civil law countries but due to non-availability of the data of considered years, we have restricted our study to merely German civil law countries to compare with the private firms of common law countries. While considering geographical regions both eastern (Asian) and western countries (European countries) are taken into consideration.

Our paper contributes to the vast literature of legal origins and conservative policies adopted by the private firms in two ways. Firstly, we conduct the study based on the different legal systems and their influence on the capital structures of private firms. Secondly, we calculated both low leverage and high cash reserves to measure conservatism rather than considering just one of them. Thirdly, we observe the differences in determinants of conservative firms during pre and post financial crises periods while considering their legal origins.

\section{Determinants of Capital Structure and Hypothesis}

All the variables considered represent capital structure theories i.e. pecking order theory given by Myers and Majluf (1984) and trade off theory of Kraus et al. (1973). These variables are mentioned as size, investments, dividends, Asset tangibility, Non-Debt Tax Shield and Profitability. Their relationships with conservative policies and hypothesis construction are mentioned as follows:

\subsection{Size}

According to (Rajan \& Zingales, 1995), large firms are more diversified, and have more access to capital markets and therefore, may have less chances to default. The argument supports the trade-off theory which suggests that the firms having large assets may borrow more indicating positive relation of debt with the size of the firms. Since our study considers the conservative policies (low leverage and high cash) of private firms, size and number of assets is expected to be small as compared to large firms and may correlate negatively with a likelihood of adopting conservative policy.

\subsection{Non-Debt Tax Shield Benefits}

Firms relying on debt financing may have negative non-debt tax shield benefits, if the firms report negative or less incomes. Which may also bring incurring expenses of paying interest. Therefore, the firms with higher non-debt tax shields use less debt in their capital structures as mentioned by DeAngelo and Masulis (1980). A number of studies evidences the negative relationship of leverage with non-debt tax Shields (Wald, 1999); (Deesomsak, Paudyal, \& Pescetto, 2004); (Viviani, 2008). In our study, where the conservative policies (low leverage and high cash holdings) are under consideration, firms may have high non-tax shield benefits because of their less reliance on debt financing. Therefore, the relationship is expected to be positive in our study with the conservative policies.

\subsection{Dividend Payouts}

The requirement of paying dividends and reducing agency costs may lead firms to external financing or may 
lower their cash reserves. Therefore, dividends may have positive relationship with external financing and negative with the cash holdings as mentioned by Easterbrook (1984); and Opler et al. (1999). Whereas, Bigelli and Sánchez-Vidal (2012) provides the evidence that in private firms where ownership structures are usually concentrated, firms accumulate cash at the end of their fiscal year and their case may differ from public firms. In civil law countries, where firms are more constrained and have family or state ownership as evident in La Porta. (2000). Since our study focuses on private firms, we expect dividend payouts are positively associated with conservative financial policy.

\subsection{Investments}

As mentioned in Bigelli (2014), our investments include both tangible and non-tangible assets and hence, is considered as a negative proxy of cashflows. It is expected to have a negative relation of investments with likelihood of financial conservative policy.

\subsection{Asset Tangibility}

Firms holding tangible assets may have inclination to render them for securing loans as mentioned by Ahmed Sheikh and Wang (2011). Consequently, asset tangibility may construct a positive relationship with leverage, but this could be possible in the case of public firms. Our study focuses on private firms with their likelihood of adopting conservative policies. Retaining cash holdings and maintaining low leverage may reduce the size of firms and hence may limit their tangible assets to minimum. Therefore, in this study, it is likely to expect a negative relationship between asset tangibility and conservative policy in this study.

\subsection{Profitability}

According to pecking order theory, firms prefer to exhaust their internal funds before considering leverage. In our study, profitability is a source of internal funds which may reduce leverage and increase the cash holdings. Therefore, we expect to have a positive relationship between the likelihood of being conservative and profitability.

The division of rest of the paper is as follows. Section 3 describes the data description. Section 4 explains methodologies. Section 5 considers the empirical findings and discussion, findings and limitations whereas, section 6 presents the conclusion.

\section{Data Description}

The data has been collected from Wharton Research Database (WRDS) for all the countries considered within time period of 2000 to 2017. The firms' data is collected with 4-digit code Standard Classification Code (SIC) of the firms in all countries considered in this study. The variables taken follow relevant theories of capital structure (Pecking order theory, Trade off theory and Financial constraints). The firms considered in sample are manufacturing, wholesale and retail, mining and quarrying, construction, water, gas and electricity, transport, storage and communications respectively.

\subsection{Dependent Variable}

As followed the fixed classification rule by Iona and Leonida (2016), this study also brings the combination of low leverage and high cash holdings. Minton and Wruck (2001) has taken the lowest debt quintile for five consecutive years whereas the firms were considered "leverage conservative" if the annual ratio of total debt to total assets belongs to the first $20 \%$ for five consecutive years. Mikkelson and Partch (2003) has considered the firm "cash conservative" if it holds more than $25 \%$ of the cash and equivalents for five conservative years.

To classify financial conservatism, both policies were combined to create new dummy variable "Financial Conservatism" as mentioned by Iona and Leonida (2016). The firms are termed as following financial conservative policy if they adopt both policies (leverage and cash conservative) together. The firms with financial conservatism are termed as 1 otherwise are taken as 0 . Hence, this study has focused on considering the financial conservatism is taken as dependent variable with fixed classification rule as per Iona and Leonida (2016). All the countries are found with majority of the manufacturing firms in the sample set.

\subsection{Independent Variables}

All the variables mentioned in table 1 represents pecking order theory, trade off theory and financial constraints (Kraus \& Litzenberger, 1973; Myers \& Majluf, 1984; Hadlock \& Pierce, 2010). The first filter excludes all those firms with extra ordinary operations and have extreme variations in assets. The second filter removes the firms with extreme financial distress. The third filter excludes the observations with extreme negative values. The debt and the cash of the firms are divided by total assets and the negative observations have been eliminated out of the dataset. The independent variables described below are winsorized at the levels of $1 \%$ and $99 \%$ before 
running the regressions. Table 2 provides the summary statistics of all the variables considered.

Table 1. Description of variables

\begin{tabular}{lll}
\hline \multicolumn{1}{c}{ Variable } & \multicolumn{1}{c}{ Measurement } & \multicolumn{1}{c}{ Literature } \\
\hline Firm Size & Log of Total Assets & Cassar and Holmes (2003); Ramlall(2009) \\
Investments & Ratio of Tangible and Intangible assets to Assets Total & Bigelli(2014) \\
Dividends & Ratio of Total Dividends to Assets Total & Bigelli(2014) \\
Asset Tangibility & Ratio of Fixed Assets to Assets Total & Cheng and Shiu (2007) \\
Non-debt-tax shield & Ratio of Depreciation Expense to Assets Total & Sheikh and Wang (2011) \\
Profitability & Ratio of Operating Income to Assets Total & Deesomsak et al. (2004) \\
\hline
\end{tabular}

Table 2. Summary statistics of variables

\begin{tabular}{cccccc}
\hline Variable & Obs & Mean & Std.Dev & Min & Max \\
\hline Investments & 51,473 & 0.38338 & 0.21349 & 0 & 0.988126 \\
Dividends & 51,473 & 0.01796 & 0.068174 & 0 & 13.3795 \\
Tax_Shiled & 51,473 & 0.035302 & 0.038332 & -0.04542 & 3.437979 \\
Profitibility & 51,473 & 0.05172 & 3.557129 & -805.654 & 3.454789 \\
Tangibility & 51,473 & 0.320339 & 0.212551 & 0 & 0.983059 \\
Size & 51,473 & 9.437168 & 2.962622 & -3.96332 & 19.01836 \\
LC & 51,473 & 0.502691 & 0.499998 & 0 & 1 \\
CC & 51,473 & 0.172595 & 0.377901 & 0 & 1 \\
FC & 51,473 & 0.146038 & 0.353148 & 0 & 1 \\
CT & 51,473 & 0.143107 & 0.139259 & -0.06109 & 1 \\
DT & 51,473 & 0.245679 & 3.243958 & -0.03803 & 572.4615 \\
\hline
\end{tabular}

\section{Methodology}

Considering the dependent variable as binary in nature, the characteristics of the conservative firms are estimated with fixed effect logit regression. Which is as follows:

$$
\operatorname{Pr}\left(\text { financial conservatism }_{i t}=1\right)=f\left(\beta_{0}+\beta_{1} x_{i t}+\beta_{2} x_{i t}+\mu_{i t}\right)
$$

Where, $f(z)=e_{z} /\left(1+e_{z}\right)$ is the cumulative logit distribution.

Logit models have a statistical advantage over probit models based on their parsimony of assumptions and consistency of estimators given by Wooldridge (2002). In addition, we consider fixed effects for the time-constant unobserved heterogeneity. Moreover, the fixed effects estimations address the issues of missing values if they may exist in some regressors.

\section{Empirical Findings and Discussion}

Our study contributes to the literature of corporate finance suggesting that the firms' capital structures and characteristics differ according to their legal origin, cetris beribus. We further provide that because of the Minority shareholder's protection law, the private firms in civil law countries tend to provide more dividend payouts as compared to common law countries. In civil law countries, due to the less creditor's right protection firms prefer to rely less on external financing as mentioned by (La Porta et al., 1997). Due to their less efficient debt enforcements and contracts, firms prefer to rely on their internal financing and may have higher tax shields as compared to those countries of common law.

In common law countries, firms have better access to the capital markets. (La Porta, Lopez-de-Silanes, \& Shleifer, 2008) argues that financial development is imminent in the common law countries since they provide better protection to external investors. In support, (Shleifer \& Vishny, 1997) suggests that the common law countries support the external investors and limits the embezzlement of internal creditors, helping the firms to expand. However, with the inclusion of external creditors it is highly likely to have conflict of interests between internal and external creditors and may arise agency problems for the firms. Since the laws support external creditors and capital markets are more efficient, the non-debt tax shields may reduce to minimum in common law countries.

\subsection{Percentages of the Firms}

Following the Table 3 , it is evident that $17 \%$ of the private firms in civil law countries have higher likelihood of adopting conservative policies comparing to 11 percent of common law countries. The results support the argument of La Porta. 2008 of efficient capital markets and better contract and debt enforcements inclines the 
firms towards external financing and hence, reduces their inclination towards adoption of conservative policies.

Table 3. Percentages for each country considered

\begin{tabular}{|c|c|c|c|c|c|c|c|}
\hline & Observations & $\begin{array}{c}\text { Leverage } \\
\text { conservative } \\
\end{array}$ & Percent & $\begin{array}{c}\text { Cash } \\
\text { Conservative }\end{array}$ & Percent & $\begin{array}{c}\text { Financial } \\
\text { Conservatism }\end{array}$ & Percent \\
\hline \multicolumn{8}{|c|}{ Common Law Countries } \\
\hline United Kingdom & 5885 & 3341 & $57 \%$ & 805 & $14 \%$ & 726 & $12 \%$ \\
\hline India & 8524 & 3206 & $38 \%$ & 921 & $11 \%$ & 778 & $9 \%$ \\
\hline Australia & 3134 & 1643 & $51 \%$ & 418 & $13 \%$ & 392 & $13 \%$ \\
\hline Pakistan & 906 & 535 & $59 \%$ & 147 & $16 \%$ & 132 & $15 \%$ \\
\hline Thailand & 1437 & 633 & $44 \%$ & 193 & $13 \%$ & 166 & $12 \%$ \\
\hline All Common & 19886 & 9358 & $47 \%$ & 2484 & $12 \%$ & 2194 & $11 \%$ \\
\hline \multicolumn{8}{|c|}{ Civil Law Countries } \\
\hline Germany & 2253 & 1218 & $54 \%$ & 366 & $16 \%$ & 335 & $15 \%$ \\
\hline Japan & 23505 & 12921 & $55 \%$ & 4974 & $21 \%$ & 4153 & $18 \%$ \\
\hline Korea & 5829 & 2378 & $41 \%$ & 1060 & $18 \%$ & 835 & $14 \%$ \\
\hline All Civil & 31587 & 16517 & $51 \%$ & 6400 & $20 \%$ & 5323 & $17 \%$ \\
\hline Total & 51473 & 25875 & $50 \%$ & 8884 & $17 \%$ & 7517 & $15 \%$ \\
\hline
\end{tabular}

Number of Observations taken in each country distinguished by their legal origin. All countries have been separated with the percentages of adoption of Financially Conservatism (Low Leverage and High Cash), Leverage Conservatism (Low leverage as in Minton and Wruck, 2001), Cash Conservatism (High Cash Holdings as in Mikkelson \& Partch, 2003).

\subsection{Persistence of the Firms}

Following Minton and Wruck. (2001), we have considered the persistence of the firms adopting the policies of financial conservatism for more than 5 years. By considering 2005 as base year, we have seen the persistence of the firms for next six years till 2011. The purpose of considering those years is the event of financial crises (affected capital structures and markets as provided by Iqbal and Kume (2011)) to observe if the firms increase or decrease their likelihood of adopting conservative policies. Moreover, table 4 exhibits that private firms in civil law countries are highly likely to adopt financial conservative policies than those in common law countries. By understanding the percentages, we exhibit that the firms have the declining trend with a sharp decline observed between 2007-2009. Therefore, it might be of interest if the private firms have some changes in their capital structures after the event of financial crises (2008).

Table 4. Persistence of the firms: Represents the percentages of firms' persistence adopting Financial conservative policy in both legal origins for the number of years (2006-2011) meanwhile 2005 has been considered as base year

\begin{tabular}{llllllll}
\hline Year & & 2006 & 2007 & 2008 & 2009 & 2010 & 2011 \\
\hline Category 1 & 100 & $74 \%$ & $59 \%$ & $35 \%$ & $21 \%$ & $14 \%$ & $10 \%$ \\
Category 2 & 100 & $88 \%$ & $67 \%$ & $47 \%$ & $38 \%$ & $31 \%$ & $27 \%$ \\
\hline
\end{tabular}

Note. Category 1 represents the Common law countries and Category 2 presents the Civil law countries.

\subsection{Parametric and Non-Parametric Estimations}

In table 5, we estimated the results by parametric and non-parametric tests to record the differences between the conservative and non-conservative private firms. With the results, we present that firms with following conservative policies are smaller in size, constrained with investments and less non-debt tax shields. The less debt tax shields are probably because of less investments and small size of the firms. Contrarily, the conservative firms pay higher dividends and profitability as compared to non-conservative firms. The estimate of high dividend supports the argument of Bigelli and Sánchez-Vidal (2012) associates the ownership structures with retention of cash at the end of fiscal years in private firms which increases the probability of providing more dividends then unconstrained firms. Similarly, private firms by following pecking order style theory, depend largely on their internal funds and hence have fewer external obligations. It may reduce their burdens to retain more profitability (operating incomes) than those which are non-conservative firms. Furthermore, the correlation matrix among the variables used in multivariate analysis is mentioned in table 6 . 
Table 5. Parametric and Non-Parametric tests

\begin{tabular}{cccccc}
\hline \multicolumn{5}{c}{ Parametric and Non-Parametric Test } & \\
\hline & Financial Conservative Firms & Non-Financial Conservative Firm & Difference & T-Test & U-Test \\
\hline Size & 8.844137 & 9.538583 & 0.6944458 & 18.8448 & 16.024 \\
Investmets & 0.2049781 & 0.4138882 & 0.2089101 & 83.5478 & 81.571 \\
Dividends & 0.0295122 & 0.0159849 & -0.0135273 & -15.9367 & -39.843 \\
Asset Tangiibility & 0.1577876 & 0.348137 & 0.1903494 & 75.6328 & 75.853 \\
Tax_Shield & 0.02875 & 0.0364224 & 0.0076724 & 16.0766 & 33.909 \\
Profitability & 0.0946987 & 0.0443701 & -0.0503286 & -1.1336 & -32.841 \\
\hline
\end{tabular}

Note. Size is the log of total assets. Investments are addition of both tangible and non-tangible fixed assets divided by total assets. Dividends are the total dividends paid divided by total assets. Asset tangibility is the ratio of fixed assets to total assets. Non- Debt Tax shield is the ratio of depreciation expense to total assets. Profitability is the ratio of operating income to total assets.

Table 6. Correlation Matrix

\begin{tabular}{|c|c|c|c|c|c|c|c|}
\hline & $\mathrm{FC}$ & Size & Investment & Dividends & Tangibility & Tax_Shield & Profitibility \\
\hline FC Dummy & 1 & & & & & & \\
\hline Size & $-0.0828^{*}$ & 1 & & & & & \\
\hline Investments & $-0.3456^{*}$ & $-0.0221^{*}$ & 1 & & & & \\
\hline Dividends & $0.0701 *$ & $-0.1509^{*}$ & $-0.0196^{*}$ & 1 & & & \\
\hline Tangibility & $-0.3163^{*}$ & $0.1486^{*}$ & $0.8145^{*}$ & $-0.0551^{*}$ & 1 & & \\
\hline Tax_Shield & $-0.0707 *$ & $-0.0994 *$ & $0.2725^{*}$ & 0.006 & $0.2024 *$ & 1 & \\
\hline Profitability & 0.005 & $0.0187 *$ & $0.0080^{*}$ & 0.0052 & 0.0066 & $-0.2255^{*}$ & 1 \\
\hline
\end{tabular}

Note. The Pearson Correlation coefficients have been reported between financial conservatism dummy variable and the explanatory variables taken as characteristics of the firms in the multivariate analysis. Size is the log of total assets. Investments are addition of both tangible and non-tangible fixed assets divided by total assets. Dividends are the total dividends paid divided by total assets. Asset tangibility is the ratio of fixed assets to total assets. Non- Debt Tax shield is the ratio of depreciation expense to total assets. Profitability is the ratio of operating income to total assets.

\subsection{Determinants of Capital Structure and the Conservative Policies of the Private Firms}

To estimate our results for multivariate analysis we have considered logit model estimator because of the binary dependent variable, with and without time dummy on the right-hand side of the equation. Our panel contains data across firms in different legal origins overtime, it is likely to have cross-sectional effects on sample of each firm, country or on a group of countries or firms contained. To address these effects, fixed effect and random effect estimation models are taken into consideration. By conducting the Hausman test, we strongly reject the null hypothesis and rely on the results estimated by fixed effect logit model with the inclusion of time dummy.

In table 7 column 3, we have considered all countries irrespective of their legal origins. Which shows that the private firms with probability to follow conservative policy are smaller in size with negative investments, less dividend payouts, having higher non-debt tax shields and high profitability. In column 4 , we have taken private firms with likelihood of having conservative policies separately while considering their legal systems of common and civil law respectively.

Table 7. Capital Structures of financially conservative firms in common and civil law countries

\begin{tabular}{|c|c|c|c|c|c|}
\hline \multicolumn{6}{|c|}{ Dependent Variable: Financial Conservatism } \\
\hline & All & All & All & Common & Civil \\
\hline & 1 & 2 & 3 & 4 & 5 \\
\hline \multirow[t]{2}{*}{ Size } & $0.0626^{* *}$ & 0.0541 & $-0.590 * * *$ & $-0.276^{* *}$ & $-0.985 * * *$ \\
\hline & $(0.0239)$ & $(0.0549)$ & $(0.0659)$ & $(0.0963)$ & $(0.113)$ \\
\hline \multirow[t]{2}{*}{ Investments } & $-14.50 * * *$ & $-14.73 * * *$ & $-15.25 * * *$ & $-14.15^{* * *}$ & $-16.63 * * *$ \\
\hline & $(0.545)$ & $(0.593)$ & $(0.610)$ & $(0.793)$ & $(0.953)$ \\
\hline \multirow[t]{2}{*}{ Dividends } & $0.961 * * *$ & -0.283 & $-0.358 *$ & $-0.446^{*}$ & $12.74 * *$ \\
\hline & $(0.0484)$ & $(0.162)$ & $(0.182)$ & $(0.178)$ & $(4.422)$ \\
\hline \multirow[t]{2}{*}{ Tangibility } & $-3.160 * * *$ & $-2.619 * * *$ & -1.269 & -0.700 & -1.075 \\
\hline & $(0.555)$ & $(0.689)$ & $(0.708)$ & $(0.893)$ & (1.128) \\
\hline \multirow[t]{2}{*}{ Tax Shield } & 2.875 & 1.245 & $1.694 *$ & 2.791 & $4.663 * * *$ \\
\hline & $(1.756)$ & $(0.912)$ & $(0.840)$ & $(2.483)$ & (1.179) \\
\hline \multirow[t]{2}{*}{ Profitability } & $2.710^{* * *}$ & $2.907 * * *$ & $3.408 * * *$ & $1.815^{* * *}$ & $5.765^{* * * *}$ \\
\hline & $(0.384)$ & $(0.352)$ & $(0.365)$ & $(0.386)$ & $(0.675)$ \\
\hline
\end{tabular}




\begin{tabular}{cccccc}
\hline Year Dummies & No & No & Yes & Yes & Yes \\
Log Liklihood & -9229.96 & -4528.51 & -4324.58 & -1376.05 & -2896.04 \\
Chi2 & 2088.49 & 2783.9 & 3191.77 & 1277.04 & 2019.69 \\
Hausman $=$ & 124.43 & & & & \\
Prob>chi2= & 0.0000 & & & & \\
\hline
\end{tabular}

Note. Policies of financial conservatism (Low leverage + High cash holdings). Leverage Conservatism as in Minton and Wruck, (2001) and Cash Conservatism as in Mikkleson and Partch (2003). As followed the fixed classification rule by (Iona \& Leonida, 2016), this study also brings the combination of low leverage and high cash holdings. The firms are termed as following financial conservative policy if they adopt both policies (leverage and cash conservative) together. The firms with financial conservatism are termed as 1 otherwise are taken as 0 . Size is the log of total assets. Investments are addition of both tangible and non-tangible fixed assets divided by total assets. Dividends are the total dividends paid divided by total assets. Asset tangibility is the ratio of fixed assets to total assets. Non- Debt Tax shield is the ratio of depreciation expense to total assets. Profitability is the ratio of operating income to total assets. *, **, *** shows the level of significance at $10 \%, 5 \%$ and $1 \%$ respectively.

Under the hypothesis established, the results highlight the differences with some similarities in common and civil law countries. Size, investments and asset tangibility present the negative relationship with the likelihood of financial conservative policies whereas, profitability provides the positive relationship with conservative policies in both legal origins. However, dividend payouts and tax shields are found with differences in their legal systems. In civil law countries, conservative policies have positive relationship with dividends contrary to the negative relationship established dividend payouts in common law countries. Non-Debt tax shield exhibits the positive relationship with conservative policies in both legal systems but not significantly in common law countries.

In table 8 , to examine the determinants of capital structure more effectively, we separated the time series with the consideration of before and after financial crises (2008). We find almost similar results estimated as in table 7 (column 4 and 5) with only a little difference of the dividend payouts in both legal origins before and after crises period. Dividends show significant negative relationship with the conservative policies in common law countries before and after financial crises whereas, in civil law countries conservative private firms have established a negative relationship before financial crises but not significantly however, after financial crises the relationship remains positive significantly. Moreover, Non-tax debt shields remain positively significant with conservative policies of civil law countries. Further details for robustness have been added into the appendix A.

Table 8. Capital Structure of financial conservative firms before and after financial crises

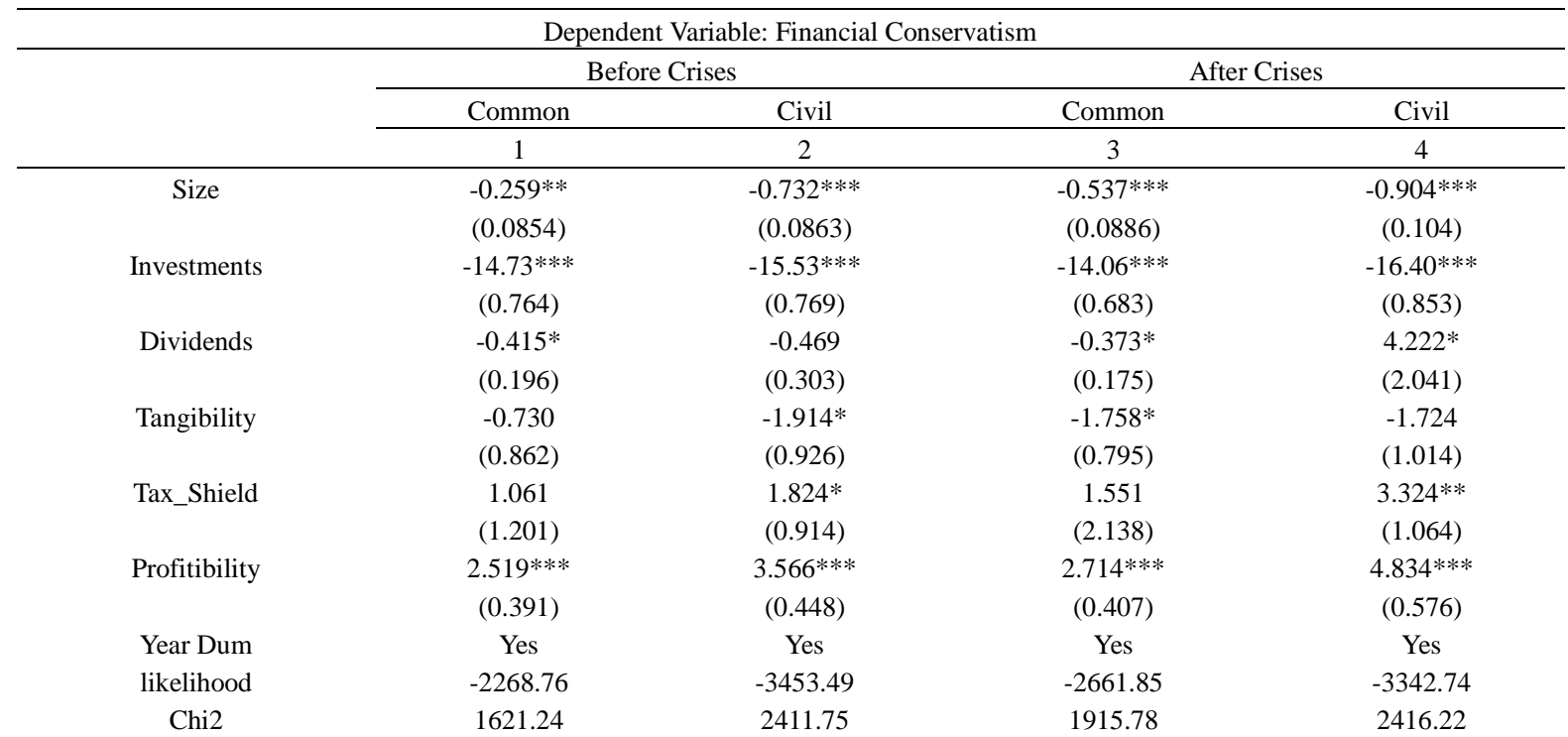

Note. Policies of financial conservatism (Low leverage + High cash holdings). Leverage Conservatism as in Minton and Wruck (2001) and Cash Conservatism as in Mikkleson and Partch (2003). As followed the fixed classification rule by (Iona \& Leonida, 2016), this study also brings the combination of low leverage and high cash holdings. The firms are termed as following financial conservative policy if they adopt both policies (leverage and cash conservative) together. The firms with financial conservatism are termed as 1 otherwise are taken as 0 . Size is the log of total assets. Investments are addition of both tangible and non-tangible fixed assets divided by total assets. Dividends are the total dividends paid divided by total assets. Asset tangibility is the ratio of fixed assets to total assets. Non- Debt Tax shield is the ratio of depreciation expense to total assets. Profitability is the ratio of operating income to total assets. *,**, *** shows the level of significance at $10 \%, 5 \%$ and $1 \%$ respectively 


\subsection{Discussion on Empirical Findings}

According to the empirical findings, size, investments and tangibility have established the negative relationship with the conservative policies in both legal origins. It confirms that the firms that are highly likely to adopt conservative policies are small in size with less investments and asset tangibility. While their intentions to have less leverage and retain high cash holdings, their investments are held constrained to acquire more assets which reduces their size as well as asset tangibility. It also proves that the conservative firms are highly exposed to financial constraints due to their limited resources.

It evidences that conservative firms may also have higher probability to follow pecking order style theory of exhausting their internal funds before approaching to external funds.

The requirement of paying dividends and reducing agency costs may lead firms to external financing or may lower their cash reserves. Therefore, dividends may have positive relationship with external financing and negative with the cash holdings as mentioned by Easterbrook (1984) and Opler et al. (1999). Whereas, Bigelli and Sánchez-Vidal (2012) provides the evidence that in private firms where ownership structures are usually concentrated, firms accumulate cash at the end of their fiscal year and their case may differ from public firms. Since our study focuses on private firms, we expect dividend payouts are positively associated with conservative financial policy.

In our findings, the variable dividend is found positively significant with conservative policies in civil law countries whereas, in common law countries they are found negatively significant. La Porta (2008) argues that the differences in laws, capital market structures and their efficiencies, which may affect the capital structures of the firms. He further provides that because of the Minority shareholder's protection law, the private firms in civil law countries tend to provide more dividend payouts as compared to common law countries. Having positive dividend payouts also means that conservative private firms in civil law countries may also have less agency issues. On the contrary, private firms in common law countries exhibit negative relationship with dividends. As mentioned by Shleifer and Vishny (1997) the common law countries have creditors' (external investors) rights protection which may assist the firms to expand and firms are highly likely to leave conservative policy for expansion. With this argument Our findings in table 4 also go along with the argument that the persistence of firms in common law countries is comparatively lower than the civil law countries' private firms. On the cost of expansions, such protection may limit the embezzlement of internal creditors(agents) but may also raise the agency problems with the negative relationship of conservative firms with dividends.

Moreover, the non-debt tax shields are also positive and significant with the conservative policies of private firms in civil law countries but remain insignificant in common law countries. La Porta (2008) believes that due to the less efficient debt enforcements and contracts, firms prefer to rely on their internal financing and may have higher tax shields as compared to those firms in common law countries.

In summary, the differences of dividend payouts and tax shields in both legal origins have their own positive and negative consequences. In civil law countries, the conservative private firms may have less agency problems due to positive dividend payouts and have higher non-debt tax shields because of less efficient debt structures of the markets but it may also bring in a negative consequence of low growth opportunities and less future investments. In contrast, conservative firms of common law countries may have negative association with dividends which may bring the high agency costs but the creditor's protection in common law and the involvement of external creditors may open the horizons for more growth opportunities and future investments.

The limitation of this study is the lack of data availability which restricts the study to the considered characteristics of the capital structure of the firms in both legal origins. Moreover, it would be interesting to observe the characteristics of the public firms in both legal origins.

\section{Conclusion}

This study emphasizes on the capital structures of the conservative private firms in two different legal origins during the time period of 2000-2017. The countries considered in each legal origin represents common law countries (UK, Australia, India, Pakistan and Thailand) and Roman backed civil law countries (Japan, South Korea, Germany) respectively. We exhibit that conservative private firms in both legal origins are negatively related with investments, asset tangibility and size. Which provides that private firms with probability of adopting conservative policies are asset constrained and may have limited growth opportunities. Whereas, dividend payouts have positive relation with conservative policies in civil law countries contrary to the negative relationship of dividends with conservative private firms in common law countries. La Porta (2008) supports our findings that in civil law countries Minority shareholder's rights protection directs the firms to pay dividends. 
Since conservative firms have low leverages and are likely to hold cash, there is a probability that private firms may pay dividends to their agents (minority shareholders) to reduce agency costs. In contrast, private firms with probability of being conservative in common law countries, established negative relationship with dividends. It exhibits that common law protects the creditor's rights (external investors) than their minority shareholders or agents. Creditor's rights and efficient debt enforcements may increase the creditor's recovery rates, but it may also increase the agency costs as mentioned by Djankov, McLiesh, and Shleifer (2007). We also exhibit that private firms in civil law countries may adopt conservative policies more than common law countries and their persistence to conservative policies is more than common law countries. Considering the financial crises (2008), it is presented that conservative private firms are less inclined towards paying dividends though not significantly in civil law countries but after financial crises dividends have been found significantly positive in civil law countries and remained negatively associated with common law countries. The study implicates the capital structures of the conservative private firms are influenced by legal systems differently. Based on the laws, efficiency of capital and debt market structures, private firms define their capital structures. Private firms following conservative policies may have financial constraints irrespective of their legal origin, but their structures may differ in terms of dividend payouts and tax shields. Moreover, to limit the private firms that are forced to adopt conservative financial policy, it is necessary for the policy makers to enable smooth functioning of credit markets in both legal origins specially in civil law countries. In contrast, minority shareholder rights in common law countries should be ensured and might not be overshadowed by the ambitious strategies of the creditors.

\section{References}

Ahmed, S. N., \& Wang, Z. (2011). Determinants of capital structure. Managerial Finance, 37(2), 117-133. https://doi.org/10.1108/03074351111103668

Bessler, W. et al. (2013). The international zero-leverage phenomenon. Journal of Corporate Finance, 23, 196-221. https://doi.org/10.1016/j.jcorpfin.2013.08.004

Bigelli, M., \& Sánchez-Vidal, J. (2012). Cash holdings in private firms. Journal of Banking and Finance, 36(1), 26-35. https://doi.org/10.1016/j.jbankfin.2011.06.004

Bigelli, M., Martín-Ugedo, J. F., \& Sánchez-Vidal, F. J. (2014). Financial conservatism of private firms. Journal of Business Research, 67(11), 2419-2427. https://doi.org/10.1016/j.jbusres.2014.02.009

Brav, O. (2009). Access to Capital, Capital Structure, and the Funding of the Firm. The Journal of Finance, 64(1), 263-308. https://doi.org/10.1111/j.1540-6261.2008.01434.x

DeAngelo, H., \& Masulis, R. W. (1980). Optimal capital structure under corporate and personal taxation. Journal of Financial Economics, 8, 3-29. https://doi.org/10.1016/0304-405X(80)90019-7

Deesomsak, R., Paudyal, K., \& Pescetto, G. (2004). The determinants of capital structure: Evidence from the Asia Pacific region. Journal of Multinational Financial Management, 14(4-5), 387-405. https://doi.org/10.1016/j.mulfin.2004.03.001

Djankov, S., McLiesh, C., \& Shleifer, A. (2007). Private credit in 129 countries. Journal of Financial Economics, 84(2), 299-329. https://doi.org/10.1016/j.jfineco.2006.03.004

Easterbrook, F. H. (1984). Two Agency-Cost Explanations of Dividends. American Economic Association, 74(4), 650-659. https://doi.org/10.1257/aer.20130189

Graham, J. (2000). How Big Are the Tax Benefits of Debt? The Journal of Finance, 55(5), 1901-1941. https://doi.org/10.1111/0022-1082.00277

Hadlock, C. J., \& Pierce, J. R. (2010). New Evidence on Measuring Financial Constraints: Moving Beyond the KZ Index. The Review of Financial Studies, 23(5), 1909-1940. https://doi.org/10.1093/rfs/hhq009

Iona, A., \& Leonida, L. (2016). Suboptimal financial policies and executive ownership in the UK: Evidence from a pre-crisis. Corporate Governance: The International Journal of Business in Society, 16(1), 187-210. https://doi.org/10.1108/CG-01-2015-0005

Iqbal, A., \& Kume, O. (2014). Impact of Financial Crisis on Firms' Capital Structure in UK, France, and Germany (June 16, 2015). Multinational Finance Journal, 18(3/4), 249-280. https://doi.org/10.17578/18-3/4-3

Korteweg, A. (2010). The Net Benefits to Leverage. The Journal of Finance, 65(6), 2137-2170. https://doi.org/10.1111/j.1540-6261.2010.01612.x 
Kraus, A., \& Litzenberger, R. H. (1973). A State-Preference Model of Optimal Financial Leverage. The Journal of Finance, 28(4), 911-922. https://doi.org/10.1111/j.1540-6261.1973.tb01415.x

Kraus. (1963). American Finance Association Optimal Investment and Financing Policy. The Journal of Finance, 18(2), 264-272.

La Porta, R. et al. (1997). Legal Determinants of External Finance. The Journal of Finance, 52(3), 1131-1150. https://doi.org/10.1111/j.1540-6261.1997.tb02727.x

La Porta, R., Lopez-de-Silanes, F., \& Shleifer, A. (2008). The Economic Consequences of Legal Origins. Journal of Economic Literature, 46(2), 285-332. https://doi.org/10.1257/jel.46.2.285

Lemmon, M. L., Roberts, M. R., \& Zender, J. F. (2008). Back to the Beginning: Persistence and the Cross-Section of Corporate Capital Structure. The Journal of Finance, LXIII(4), 1575-1608. https://doi.org/10.1111/j.1540-6261.2008.01369.x

Mikkelson, W., \& Partch, M. (2003). Do Persistent Large Cash Reserves Hinder Performance? Journal of Financial and Quantitative Analysis, 38(2), 275-294. https://doi.org/10.2307/4126751

Minton, B. A., \& Wruck, K. H. (2002). Financial Conservatism: Evidence on Capital Structure from Low Leverage Firms (July 9, 2001). AFA 2002 Atlanta; Dice Ctr. Working Paper No. 2001-6. https://doi.org/10.2139/ssrn.269608

Myers, S. C., \& Majluf, N. S. (1984). Corporate financing and investment decisions when firms have information that investors do not have. Journal of Financial Economics, 13(2), 187-221. https://doi.org/10.1016/0304-405X(84)90023-0

Opler, T. et al. (1999). The determinants and implications of corporate cash holdings. Journal of Financial Economics, 52(1), 3-46. https://doi.org/10.1016/S0304-405X(99)00003-3

Porta, R. La et al. (2000). Investor Protection and Corporate Governance. Journal of Financial Economics, 58, 3-27. https://doi.org/10.1016/S0304-405X(00)00065-9

Rajan, R. G., \& Zingales, L. (1995). What Do We Know about Capital Structure? Some Evidence from International Data. The Journal of Finance, 50(5), 1421-1460. https://doi.org/10.1111/j.1540-6261.1994.tb00086.x

Shleifer, A., \& Vishny, R. W. (1997). A Survey of Corporate Governance. Journal of Finance, 52(2), 737-783. https://doi.org/10.1017/CBO9781107415324.004

Strebulaev, I. A., \& Yang, B. (2013). The mystery of zero-leverage firms. Journal of Financial Economics, 109(1), 1-23. https://doi.org/10.1016/j.jfineco.2013.02.001

Viviani, J. L. (2008). Capital structure determinants: An empirical study of French companies in the wine industry. International Journal of Wine Business Research, 20(2), 171-194. https://doi.org/10.1108/17511060810883786

Wald, J. K. (1999). How Firm Characteristics Affect Capital Structure: an International Comparison. Journal of Financial Research, 22(2), 161-187. https://doi.org/10.1111/j.1475-6803.1999.tb00721.x

\section{Appendix A}

Table A1. Civil law Countries: Conservative Private firms before and After crises (2008)

\begin{tabular}{|c|c|c|c|c|c|c|}
\hline \multicolumn{7}{|c|}{ Dependent Variable: Financial Conservatism } \\
\hline & \multicolumn{3}{|c|}{ Before Crises } & \multicolumn{3}{|c|}{ After Arises } \\
\hline & DEU & JPN & KOR & $\mathrm{DEU}$ & JPN & KOR \\
\hline & 1 & 2 & 3 & 4 & 5 & 6 \\
\hline \multirow[t]{2}{*}{ Tangibility } & -1.102 & $-2.495 *$ & -1.693 & $-4.055 * *$ & $-3.619 * *$ & $-3.138 *$ \\
\hline & $(1.363)$ & $(1.128)$ & $(1.060)$ & $(1.281)$ & $(1.113)$ & $(1.232)$ \\
\hline \multirow[t]{2}{*}{ Profitability } & $2.463 * * *$ & $3.255^{* * * *}$ & $2.817 * * *$ & $4.314 * * *$ & $5.345^{* * *} *$ & $4.979 * * *$ \\
\hline & $(0.519)$ & $(0.508)$ & $(0.461)$ & $(0.722)$ & $(0.665)$ & $(0.784)$ \\
\hline \multirow[t]{2}{*}{ Tax_Shield } & 0.499 & 0.931 & 1.819 & $3.593 * *$ & $-7.873 * *$ & -1.280 \\
\hline & $(1.178)$ & (1.031) & $(0.977)$ & (1.338) & $(2.626)$ & $(2.964)$ \\
\hline \multirow[t]{2}{*}{ Dividend } & -0.675 & -0.598 & -0.555 & $2.960^{*}$ & $6.281 * *$ & $4.863^{*}$ \\
\hline & $(0.612)$ & $(0.342)$ & $(0.744)$ & $(1.223)$ & $(2.286)$ & $(2.256)$ \\
\hline
\end{tabular}




\begin{tabular}{ccccccc}
\hline Size & $-0.354^{* *}$ & $-0.637 * * *$ & $-0.495^{* * *}$ & $-0.918^{* * *}$ & $-1.037^{* * *}$ & $-0.964 * * *$ \\
& $(0.116)$ & $(0.0985)$ & $(0.101)$ & $(0.155)$ & $(0.118)$ & $(0.154)$ \\
Investments & $-15.70^{* * *}$ & $-17.91^{* * *}$ & $-11.96^{* * *}$ & $-14.35^{* * *}$ & $-15.05^{* * *}$ & $-13.99 * * *$ \\
& $(1.137)$ & $(0.949)$ & $(0.875)$ & $(0.984)$ & $(0.947)$ & $(1.027)$ \\
Year Dum & Yes & Yes & Yes & Yes & Yes & Yes \\
\hline
\end{tabular}

Note. Policies of financial conservatism (Low leverage + High cash holdings). Leverage Conservatism as in Minton and Wruck (2001) and Cash Conservatism as in Mikkleson and Partch (2003). As followed the fixed classification rule by (Iona \& Leonida, 2016), this study also brings the combination of low leverage and high cash holdings. The firms are termed as following financial conservative policy if they adopt both policies (leverage and cash conservative) together. The firms with financial conservatism are termed as 1 otherwise are taken as 0 . Size is the log of total assets. Investments are addition of both tangible and non-tangible fixed assets divided by total assets. Dividends are the total dividends paid divided by total assets. Asset tangibility is the ratio of fixed assets to total assets. Non- Debt Tax shield is the ratio of depreciation expense to total assets. Profitability is the ratio of operating income to total assets. *,**,*** shows the level of significance at $10 \%, 5 \%$ and $1 \%$ respectively.

Table A2. Common Law Countries: Conservative Private firms before and after crises (2008)

\begin{tabular}{|c|c|c|c|c|c|c|c|c|c|c|}
\hline \multicolumn{11}{|c|}{ Dependent Variable: Financial Conservatism } \\
\hline & \multicolumn{5}{|c|}{ Before Crises } & \multicolumn{5}{|c|}{ After Crises } \\
\hline & UK & AUS & IND & PAK & THA & UK & AUS & IND & PAK & THA \\
\hline & 1 & 2 & 3 & 4 & 5 & 6 & 7 & 8 & 9 & 10 \\
\hline Tangibility & $\begin{array}{l}-1.526 \\
(1.139)\end{array}$ & $\begin{array}{l}-1.517 \\
(1.260)\end{array}$ & $\begin{array}{l}-0.410 \\
(1.171)\end{array}$ & $\begin{array}{l}-1.578 \\
(1.410)\end{array}$ & $\begin{array}{l}-2.398 \\
(1.341)\end{array}$ & $\begin{array}{c}-3.901 * * * \\
(1.051)\end{array}$ & $\begin{array}{c}-4.841 * * * \\
(1.185)\end{array}$ & $\begin{array}{c}-3.922 * * * \\
(1.127)\end{array}$ & $\begin{array}{c}-4.119 * * \\
(1.323)\end{array}$ & $\begin{array}{c}-4.288 * * \\
(1.340)\end{array}$ \\
\hline Profitability & $\begin{array}{c}2.654 * * * \\
(0.487)\end{array}$ & $\begin{array}{c}2.276^{* * * *} \\
(0.467)\end{array}$ & $\begin{array}{c}2.530^{* * * *} \\
(0.451)\end{array}$ & $\begin{array}{c}2.682 * * * \\
(0.524)\end{array}$ & $\begin{array}{c}2.340 * * * \\
(0.502)\end{array}$ & $\begin{array}{c}3.775^{* * * *} \\
(0.637)\end{array}$ & $\begin{array}{c}2.549 * * * \\
(0.614)\end{array}$ & $\begin{array}{c}4.095^{* * * *} \\
(0.631)\end{array}$ & $\begin{array}{c}5.217 * * * \\
(0.809)\end{array}$ & $\begin{array}{c}4.595^{* * *} * \\
(0.799)\end{array}$ \\
\hline Tax_Shield & $\begin{array}{c}1.107 \\
(1.198)\end{array}$ & $\begin{array}{c}0.671 \\
(1.177)\end{array}$ & $\begin{array}{c}0.818 \\
(1.123)\end{array}$ & $\begin{array}{c}1.045 \\
(1.238)\end{array}$ & $\begin{array}{c}0.771 \\
(1.173)\end{array}$ & $\begin{array}{c}0.777 \\
(2.614)\end{array}$ & $\begin{array}{l}-1.347 \\
(2.916)\end{array}$ & $\begin{array}{l}-3.304 \\
(3.053)\end{array}$ & $\begin{array}{l}-2.032 \\
(3.317)\end{array}$ & $\begin{array}{l}-3.399 \\
(3.216)\end{array}$ \\
\hline Dividend & $\begin{array}{l}-0.505 \\
(0.314)\end{array}$ & $\begin{array}{l}-0.637 \\
(0.583)\end{array}$ & $\begin{array}{l}-0.516 \\
(0.289)\end{array}$ & $\begin{array}{l}-0.589 \\
(0.454)\end{array}$ & $\begin{array}{l}-0.576 \\
(0.440)\end{array}$ & $\begin{array}{l}-0.383 \\
(0.217)\end{array}$ & $\begin{array}{l}5.826^{*} \\
(2.838)\end{array}$ & $\begin{array}{c}3.029 \\
(2.618)\end{array}$ & $\begin{array}{l}4.454 \\
(2.940)\end{array}$ & $\begin{array}{c}3.059 \\
(1.904)\end{array}$ \\
\hline Size & $\begin{array}{c}-0.329 * * \\
(0.112)\end{array}$ & $\begin{array}{c}-0.339 * * \\
(0.111)\end{array}$ & $\begin{array}{c}-0.409 * * * \\
(0.0988)\end{array}$ & $\begin{array}{c}-0.367 * * \\
(0.117)\end{array}$ & $\begin{array}{c}-0.388 * * * \\
(0.117)\end{array}$ & $\begin{array}{c}-0.776^{* * *} \\
(0.140)\end{array}$ & $\begin{array}{c}-0.967 * * * \\
(0.149)\end{array}$ & $\begin{array}{c}-1.018^{* * *} * \\
(0.122)\end{array}$ & $\begin{array}{c}-1.108 * * * \\
(0.166)\end{array}$ & $\begin{array}{c}-1.148 * * * \\
(0.168)\end{array}$ \\
\hline Investments & $\begin{array}{c}-14.92 * * * \\
(0.960)\end{array}$ & $\begin{array}{c}-14.24 * * * \\
(1.043)\end{array}$ & $\begin{array}{c}-15.06^{* * *} \\
(1.031)\end{array}$ & $\begin{array}{c}-15.40^{* * *} * \\
(1.197)\end{array}$ & $\begin{array}{c}-14.17^{* * *} \\
(1.108)\end{array}$ & $\begin{array}{c}-14.74 * * * \\
(0.842)\end{array}$ & $\begin{array}{c}-12.61 \text { *** } \\
(0.930)\end{array}$ & $\begin{array}{c}-12.84 * * * \\
(0.943)\end{array}$ & $\begin{array}{c}-13.89 * * * \\
(1.075)\end{array}$ & $\begin{array}{c}-13.71 * * * \\
(1.077)\end{array}$ \\
\hline Year Dum & Yes & Yes & Yes & Yes & Yes & Yes & Yes & Yes & Yes & Yes \\
\hline
\end{tabular}

Note. Policies of financial conservatism (Low leverage + High cash holdings). Leverage Conservatism as in Minton and Wruck (2001) and Cash Conservatism as in Mikkleson and Partch (2003). As followed the fixed classification rule by (Iona \& Leonida, 2016), this study also brings the combination of low leverage and high cash holdings. The firms are termed as following financial conservative policy if they adopt both policies (leverage and cash conservative) together. The firms with financial conservatism are termed as 1 otherwise are taken as 0 . Size is the log of total assets. Investments are addition of both tangible and non-tangible fixed assets divided by total assets. Dividends are the total dividends paid divided by total assets. Asset tangibility is the ratio of fixed assets to total assets. Non- Debt Tax shield is the ratio of depreciation expense to total assets. Profitability is the ratio of operating income to total assets. *, **, *** shows the level of significance at $10 \%, 5 \%$ and $1 \%$ respectively.

\section{Copyrights}

Copyright for this article is retained by the author(s), with first publication rights granted to the journal.

This is an open-access article distributed under the terms and conditions of the Creative Commons Attribution license (http://creativecommons.org/licenses/by/4.0/). 